Acting in the Cinema 
This page intentionally left blank 


\section{Acting in the Cinema}

\section{James Naremore}

University of California Press

Berkeley Los Angeles London 
University of California Press

Berkeley and Los Angeles

University of California Press, Ltd.

London, England

(C) 1988 by The Regents of the University of California First Paperback Printing 1990

Library of Congress Cataloging-in-Publication Data

Naremore, James.

Acting and performance in the American cinema / James Naremore.

p. $\mathrm{cm}$.

Bibliography: $p$.

Includes index.

ISBN 978-0-520-07194-0 (ppb.)

1. Motion picture acting. 2. Motion picturesUnited States.

I. Title.

PN1995.9.A26N37 1988

$791.43^{\prime} 028$ - dc 19

Printed in the United States of America

$$
\begin{array}{lllll}
5 & 6 & 7 & 8 & 9
\end{array}
$$

Illustrations courtesy of Columbia Pictures, MGM/UA, RKO. Paramount Pictures, Samuel Goldwyn, Universal Pictures, and Warner Communications.

The paper used in this publication meets the minimum requirements of American National Standard for Information Sciences-Permanence of Paper for Printed Library Materials, ANSI Z39. 48-1984. @ 
For Darlene J. Sadlier 
This page intentionally left blank 